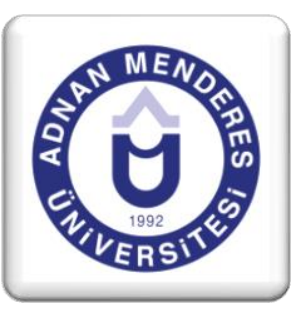

\section{Dünya'da Hayvan Refahı Uygulamalarının Ekonomik ve Sürdürülebilirlik Açısından Değerlendirilmesi ${ }^{1}$}

Hülya SERT ${ }^{2}$, Ayșe UZMAY ${ }^{3}$

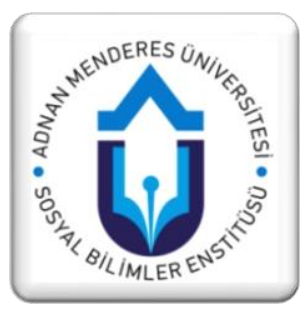

\title{
ÖZET
}

19. yy’daki hayvancılık uygulamaları sonucu hayvanlar kötü muamele ve barınak koşullarına maruz bırakılmış, genetik seçilimler sonucu canlı çeşit ve üretkenliği tahrip edilmiştir. Bir taraftan hayvanların acı ve ıstırap çektiği üretim sistemlerine getirilen eleştiriler, diğer taraftan doğal dengenin tekrar sağlanması için dikkat çeken çevreci politikaların varlığı yeni hayvancılık uygulamaları ihtiyacını doğurmuştur.

Hayvan refahı, "iyi halde olmak, mutluluk" anlamında kullanılmakta ve tam olarak "iyi bir halde olma durumunu" belirtmektedir. Günümüzde hayvan refahı; üreticilerin verimliliğini arttırıcı bir faktör, uluslararası kuruluşlar için önemli bir sürdürülebilirlik kriteri olmuştur. Daha iyi koşullarda, uygun muamele gösterilerek yetiştirilen hayvanların daha üretken olması, ölüm ve yaralanma oranlarının azalması, üreticilerin ekonomik etkinlik sağlamasına katkı sağlamaktadır. Ayrıca hayvanların üretkenliğine olumlu etkisi olan hayvan refahı, sürdürülebilir hayvancılık uygulamalarının da vazgeçilmez bir parçasıdır. Hayvan refahı uygulamaları ile birlikte çevreye duyarlı, ekolojik ve ekonomik olarak üretimi kontrol altına alan sürdürülebilirlik hedefine ulaşılabilecektir.

Bu çalışmanın üç ana amacı bulunmaktadır. Birincisi, hayvan refahı kavramını 1964 'te yayınlanan Brambell Raporu'ndan yola çıkarak günümüzde kabul görülen tanımına kadar tarihsel perspektifte incelemektir. İkincisi, hayvan refahında kullanılan ölçüm metotları ve sonuçlarının ekonomik ve sürdürülebilirlik ilişkisi kapsamında değerlendirilmesidir. Üçüncüsü ise hangi önlemlerin alınması gerektiğine dikkat çekmektir. Çalışmanın ana materyalini uluslararası kuruluşlarının raporları ile bilimsel çalışmalar oluşturmaktadır. Çalışma sonucunda hayvan refahı kriterlerine uyum için, sadece üreticilerin değil, tüketicilerin de bilinçlendirilmesi gerektiği vurgulanmıştır. Ayrıca, politika belirleyiciler tarafından cezai yaptırımların uygulanmasının önemine dikkat çekilmiştir. Ek olarak, bölge ve ülke bazında multidisipliner çalışmalar yoluyla, hayvan refahının sürdürülebilirlik ve ekonomik ilişkilerinin daha iyi anlaşılacağı belirtilmiştir.

Anahtar Kelimeler: Sürdürülebilirlik, Hayvan Refahı, Hayvan İhtiyaç Endeksi, Toplum Refahı

Jel Kod: Q01, Q18, I30

\footnotetext{
${ }^{I}$ EUREFE International Congress, Aydın İktisat Fakültesi, 27 Temmuz 2017, Aydın.

2 Yüksek Lisans Öğrencisi, Ege Üniversitesi Ziraat Fakültesi Tarım Ekonomisi Bölümü, Bornova, İzmir

3 .Doç.Dr., Ege Üniversitesi Ziraat Fakültesi Tarım Ekonomisi Bölümü, Bornova, İzmir
} 


\title{
Assessment of Economical Aspects and Sustainability of Global Animal Welfare Practices
}

\begin{abstract}
Animals were exposed to mistreatment and unsuitable shelter conditions as a result of livestock practices in the 19th century, species and reproductivity were harmed due to genetic selection. On one hand, criticism for the production systems in which animals suffer and experience pain, and on the other hand existence of significant environmental policies to restore natural balance have led to a need for new animal husbandry practices.

The term animal welfare is used in the sense of "being well and happy" and refers to "the state of being well" . Today, animal welfare has become a factor that enhances the efficiency of animal farmers and a sustainability criterion for international organizations. Animals that are kept and handled in better and suitable conditions are more productive and have lower mortality and injury rates and this allows animal farmers to achieve economic efficiency. Animal welfare, which also has a positive effect on animal productivity, is an indispensable part of animal husbandry. Using Animal welfare practices, the sustainability goal which is environmentally friendly, ecological and economic to control animal farming can be achieved.

This study has three main objectives. The first one is to review the concept of animal welfare starting from the Brambell Report published in 1964 and up to its definition commonly accepted today, with a historical perspective. The second one is to evaluate the measurement methods and results used for animal welfare in terms of economics and sustainability relationship. The third one is to draw attention to the type of measures that should be taken. The main material of this study consists of reports of international organizations and scientific studies. The study conclusion points out that not just animal farmers but also consumers should have better and raised awareness in order to comply with the animal welfare criteria. In addition, the importance of penal sanctions by policy makers is also emphasized. Furthermore, sustainability and economics relationships of animal welfare can be better understood through local and regional multidisciplinary studies .
\end{abstract}

Key Words: Sustainability, Animal Welfare, Animal Need Index, Community Welfare 


\section{Giris}

1950'lerde yaşanan“ Yeşil Devrim” adı ile bilinen yeni üretim sistemi, insan hayatının vazgeçilmez bir unsuru olan hayvancılık faaliyetini de derinden etkilemiştir. Söz konusu yeni üretim sistemi verim odaklı olmuştur. Verimliliği arttırmak amacıyla üretim yapan yetiştiriciler, nihai hedeflerine ulaşmak amacıyla hayvanlarını kötü koşullara, acı ve ızdıraba maruz bırakmışlardır. Kötü koşullara tepki olarak gelişmeye başlayan refah algısı, 20. yy'dan itibaren farklı bilim disiplinlerin çalışma konusu olmuştur.

Günümüzde hayvan refahı; üreticilerin verimliliğini arttırıcı bir faktörken, özellikle gelişmiş ülkelerde tüketicilerin hayvansal ürünleri tercih ederken aradıkları bir kriter; hükümetler için de ticarette önemli bir ön koşuldur. Daha iyi koşullarda, türüne uygun muamele gösterilerek yetiştirilen hayvanların daha üretken olması ekonomistlerin hayvan refahı tartışmalarında yer almasina neden olmuştur.

İlk kez 1964 Brambell Raporu'nda yer alan hayvan refahı ile ilgili yapılan çalışmalar küresel düzeyde 20. Yy'ın ikinci yarısından itibaren hız kazanmıştır. Avrupa'da ve Amerika Birleşik Devletleri'nde yürürlüğe konulan yasalar, diğer taraftan araştırma sonuçları hayvan refahını ileri düzeye taşımada büyük gelişmeler kat etmiştir. Bununla birlikte özellikle hayvan refahını ekonomi ve sürdürebilirlik kapsamında ele alan çalışmaların azlığı dikkati çekmektedir.

Bu çalışmanın üç ana amacı bulunmaktadır. Birincisi, hayvan refahı kavramını 1964'te yayınlanan Brambell Raporu'ndan yola çıkarak günümüzde kabul görülen tanımına kadar tarihsel perspektifte incelemektir. İkincisi, hayvan refahında kullanılan ölçüm metotları ve sonuçlarının ekonomik ve sürdürülebilirlik kapsamında değerlendirilmesidir. Üçüncüsü ise Dünya'da ve Türkiye'de hangi önlemlerin alınması gerektiğine dikkat çekmektir. Çalışmanın ana materyalini uluslararası kuruluşlarının raporları ile bilimsel çalışmalar oluşturmaktadır.

\section{Hayvan Refahının Kavramsal Açıdan İncelenmesi}

Refah, TDK'ye göre kelime anlamı olarak 'Bolluk, rahatlık ve varlık içinde yaşama' anlamına gelmektedir (TDK, 2017). Modern refah iktisatçıları, refah kavramını 'talebin karşılanması olgusu veya ihtiyaçların tatmini' olarak tanımlamaktadır (Erdal, 2012:10). Tüketici fazlası, tüketicilerin ekonomik refahının bir ölçütü iken üretici fazlası, üreticilerin ekonomik refahının bir ölçütüdür. Sosyal refah ise, üretici ve tüketici fazlasının toplamından oluşmaktadır.

Hayvan refahı, insan refahını etkileyen gıda kaynaklı faktörlerin başında gelmektedir. Hayvan refahının iyileştirilmesi, insan sağlığına ve refahına da pozitif katkı sağlamaktadır. Hayvan refahının iyileştirilmesiyle pozitif etkilenecek insan refahı sosyal refahın önemli bir parçası olup iyileştirilmesinde önemli bir unsur olacaktır (WSPA,2007). Ayrıca iyileştirilen hayvan refahının ekonomik etkinliği sağlayarak verimliliği arttırması ile sürdürülebilirlik hedeflerinin gerçekleşmesi sürecinde önemli bir aktör olup süreci hızlandıracaktır. Söz konusu ekonomik ve ekolojik iyileşme sosyal refahının iyileştirilmesinde dolaylı katkıları da beraberinde getirecektir. Gida ve tarım politikalarının belirlenmesinde hayvan refahı ile entegre bir yaklaşımın benimsenmesiyle açlığa son verme, gıda güvenliğini sağlama hedeflerine ulaşılabilecektir. Bu hedeflerin ulaşılabilirliği toprak, su ve biyolojik çeşitliliğin gelecekteki varlığına bağlı olduğundan çevre açısından sürdürülebilir olması önemlidir (CIWF, 2014). 
Hayvan refahı kavramı ilk defa 1911' de Avrupa Hayvan Hakları Kanunu içerisinde yer almıştır. Avrupa ve AB'de 20. yy'ın başında başlayan tarihsel süreç, 1950'lerden sonra hız kazanmıştır. Günümüzde hem Avrupa'da hem de AB'de mevzuat çalışmaları ile birlikte hayvan refahı uygulamalarına yönelik projeler de son derece önemlidir (Tablo 1).

Tablo 1: Avrupa'da, AB'de ve Türkiye'de mevzuatlar

\begin{tabular}{|c|c|c|}
\hline Avrupa'daki Durum & AB'deki Durum & Türkiye'deki Durum \\
\hline 1911- Hayvanları Koruma Kanunu & $\begin{array}{l}\text { 1974- Hayvanların Kesimine } \\
\text { Yönelik Kanun }\end{array}$ & 2004- Hayvanları Koruma Kanunu \\
\hline $\begin{array}{l}\text { 1951- Hayvan Refahı Enstitüsünün } \\
\text { Kurulmas1 }\end{array}$ & $\begin{array}{l}\text { 1976- Çiftlik Hayvanlarının } \\
\text { Korunması Kanunu }\end{array}$ & 2004- Organik Tarım Kanunu \\
\hline 1957- Roma Antlaşması & $\begin{array}{l}\text { 1977- Hayvan Nakillerine İlişkin } \\
\text { Kanun }\end{array}$ & $\begin{array}{l}\text { 2010- Veteriner Hizmetleri, Bitki } \\
\text { Sağlığı, Gida ve Yem Kanunu }\end{array}$ \\
\hline $\begin{array}{l}\text { 1964- Ruth Harrison: Hayvan } \\
\text { Makineleri } \\
\text { Brambell Raporu }\end{array}$ & $\begin{array}{l}\text { 1988- Yumurtacı Tavuklara } \\
\text { Yönelik Kanun }\end{array}$ & $\begin{array}{l}\text { 2011- Hayvanların Nakilleri } \\
\text { Sırasında Refahı ve Korunması } \\
\text { Yönetmeliği }\end{array}$ \\
\hline 1972- Hayvanları Koruma Kanunu & $\begin{array}{l}\text { 1991- Nakiller Sırasındaki Taşıma } \\
\text { Süreleri ve Hayvan Yoğunluklarına } \\
\text { İlişkin Yönetmelik }\end{array}$ & $\begin{array}{l}\text { 2014- Buzağıların Korunması ile } \\
\text { İlgili Yönetmelik }\end{array}$ \\
\hline 1974- Hayvan Kesimi Yasası & $\begin{array}{l}\text { 1991- Buzağı ve Domuzlara İlişkin } \\
\text { Kanun }\end{array}$ & \\
\hline $\begin{array}{l}\text { 1978- Hayvan Hakları Evrensel } \\
\text { Beyannamesi }\end{array}$ & $\begin{array}{l}\text { 1993- Hayvanların Kesim Sirasında } \\
\text { Korunmasına Yönelik Kanun }\end{array}$ & \\
\hline 1996- Taşımada Hayvan Refahı & $\begin{array}{l}\text { 1998- Çiftlik Hayvanlarını Koruma } \\
\text { Yasası }\end{array}$ & \\
\hline $\begin{array}{l}\text { 1997- Hayvanları Koruma ve } \\
\text { Refahı }\end{array}$ & 1998- Amsterdam Antlaşması & \\
\hline
\end{tabular}

Kaynak: Yaşar ve İzmirli, 2006; Matheny and Leahy, 2007

Türkiye'ye bakıldığında ise, gerçek anlamda ilk çalışmalar ancak 21.yy' in başında gerçekleştiği dikkat çekmektedir. Yapılan çalışmalar refah mevzuatları ve uygulamalarına dönük olmuş, hayvan refahının ekonomik ve sürdürülebilirlik kapsamında değerlendirilmesi ile ilgili çalışmalar yok denecek kadar az sayıdadır.

Hayvan refahı kavramı, literatürde ilk kez 1964'te hayvanların kötü yaşam standartlarına tepki olarak oluşturulan İngiliz Komitesi tarafından yayınlanan Brambell Raporu'nda yer almıştır. "Brambell Raporu" ile formel bir disiplin olarak kabul edilmeye başlanan hayvan refahıyla birlikte refahın ölçümü ve refah göstergeleri de uluslararası düzeyde tartışma konusu olmuştur. "Brambell Raporu"nda yer alan 5 temel özgürlük alanı şunlardır:

1. Hayvanlar açlık ve susuzluk çekmemeli, temiz suya ve sağlıklı uygun yeme erişebilmelidir.

2. Hayvanlar, rahatsızlık durumundan uzak olmalı, insanc1l şekilde korunmalı ve rahat bir dinlenme alanı sağlanmalıdır.

3. Önleme veya hızlı tedavi ile hayvanlar ağrı, yaralanma ve hastalıklardan uzak tutulmalidır.

4. Hayvanlar, yeterli alana ve imkânlara sahip olmalı ve kendi türündeki hayvanlarla temas kurmalıdır.

5. Hayvanlar korku ve sıkıntıdan uzak olmalı, aksi takdirde tedaviye tabi olmalıdır.

$\mathrm{Bu}$ beş temel özgürlük alanı içerisinde bulunduğu dönemde hayvanların maruz kaldığı kötü refah koşullarını ortadan kaldırmak amacıyla ortaya atılmış ve konunun önemine dikkat çekmiştir. 
Özgürlük sınırlarının ne olması değil ne olmaması gerektiğine odaklanması nedeniyle kötü refah koşullarının ortadan kaldırılmasından sonra olması gereken hayvan refahı seviyesi üzerine araştırmalara ihtiyaç duyulmuştur. Bu ihtiyacı karşılamak amacıyla günümüzde en yaygın kullanılan hayvan refahı ölçüm metotları ise çalışmanın üçüncü bölümümnde yer almaktadir.

\section{Hayvan Refahında Kullanılan Ölçüm Metotları}

Günümüzde Hayvan Refahı tanımı 4 temel ilke ve bu ilkeler doğrultusunda belirlenmiş 12 kriter ile yapılmaktadır. Bu 4 temel ilke; iyi barınma, iyi beslenme, iyi sağlık ve uygun davranıştır. Hayvan refahının ölçülebilmesi için 30' dan fazla ölçüm gerçekleştirilmekte ve hayvan refahına ilişkin skor değerler elde edilmektedir. Ölçümlerden elde edilen skor değerler 12 kriter skorunu, kriter skorları da 4 temel ilkenin skor değerlerini oluşturmaktadır. $\mathrm{Bu}$ sayede, çiftliklerde genel hayvan refahı değerlendirilmesine imkan tanınmaktadır.

\subsection{Dört Temel İlke ile Hayvan Refahının Ölçülmesi}

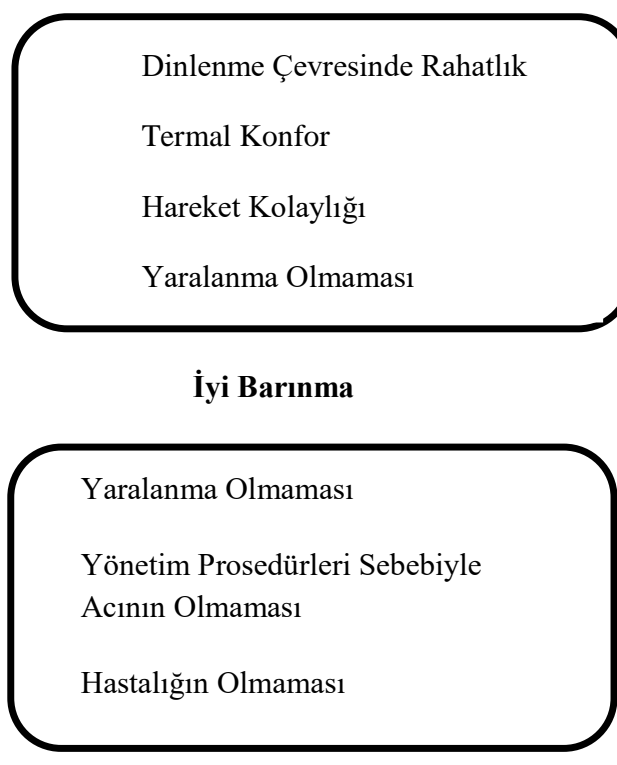

İyi Sağlık
Uzun Süre Aç Kalmama

Uzun Süre Susuz Kalmama

Sosyal Davranışların Anlatımı

Pozitif Duygusal Durum

İyi Bir İnsan Hayvan İlişkisi

Diğer Davranışların Anlatımı

Uygun Davranış

Şekil 1: Dört temel ilke ve on iki kriter

Kaynak: WQ, 2009:16

\subsection{Hayvan İhtiyaç Endeksi ( ANI-35L Modeli)}

Hayvan ihtiyaç endeksi(ANI), hayvan refahı ölçümünde en çok kullanılan yöntemlerden biridir. Hayvan ihtiyaç endeksi, çiftliklerde hayvan refahının değerlendirilmesi ihtiyacını karşılamak amacıyla uygun ve kapsamlı bir değerlendirme aracı olarak geliştirilmiş̧tir. $\mathrm{Bu}$ indeks ilk olarak Avusturya ve Almanya'da çeşitli çiftlik hayvanlarına ilişkin değerlendirmede kullanılmıştır (Bartussek, 2001:35). 
Hayvan ihtiyaç endeksi, hayvan refahını değerlendirmek için beş bileşene sahiptir. $\mathrm{Bu}$ bileşenler şunlardır (Seo, 2007:221);

1. Hareket kolaylığı ve gezebilmesi,

2. Hayvanın sosyal etkileşimi,

3. Hayvanların yatak alanı ve türü,

4. Barınakta aydınlatma ve hava koşulları

5. Hayvan Bakımı

$\mathrm{Bu}$ beş kategoride yapılan değerlendirmeler sonucu her birinden çeşitli parametreler aracılığıyla puanlama gerçekleștirilmektedir. Elde edilen skor -9.0 ile +46.0 arasında değişebilmekte ve yüksek skor puanları daha iyi refah düzeylerini göstermektedir Bartussek, (2001), hayvan refahı değerlendirmeleri için skor 28 'den büyük olduğunda çok uygun, 24 ile 28 arası uygun, 21 ile 24 arası zayıf, 11 ile 16 arası az elverişli ve $<11$ olması durumunda elverişsiz olmak üzere beş kategori tanımlamıştır (Tablo 2).

Tablo 2: HIE skor değerlendirmesi (HIE skor aralığı ' -9 ile +46')

\begin{tabular}{|c|c|}
\hline HIE Skoru & Refah Değerlendirmesi \\
\hline$<11$ & Uygun Değil \\
\hline $11-<16$ & Sinırda Uygun \\
\hline $16-<21$ & Kismen Uygun \\
\hline $21-<24$ & Oldukça Uygun \\
\hline $24-28$ & Uygun \\
\hline$>28$ & Çok Uygun \\
\hline
\end{tabular}

Kaynak: Bartussek, 2001:36

\subsection{Hayvanların İyi Barınma Koşullarına Sahip Olması}

Çiftlik hayvanlarının iyi barınak koşullarına sahip olup olmaması da hayvan refahının önemli bir göstergesidir. İyi barınak koşulları, çiftlik hayvanlarına sağlanan yatak alanı ve gezinti alanının yeterliliğinin yanında kullanılan yatak malzemesi de önemli bir refah göstergesi olarak kabul edilmektedir (Tablo 3).

Tablo 3: İyi barınma koşulları: süt sığırı örneği

\begin{tabular}{|c|c|c|c|}
\hline Hayvan Kütlesi (kg) & Yatak Alanı $\left(\boldsymbol{m}^{\mathbf{2}}\right)$ & Gezinti Alanı $\left(\boldsymbol{m}^{\mathbf{2}}\right)$ & Toplam Alan /İnek $\left.\mathbf{( m}^{\mathbf{2}}\right)$ \\
\hline $\mathbf{2 0 0}$ & 3.5 & 2.5 & 6.0 \\
\hline $\mathbf{3 0 0}$ & 4.5 & 2.5 & 7.0 \\
\hline $\mathbf{4 0 0}$ & 5.5 & 2.5 & 8.0 \\
\hline $\mathbf{5 0 0}$ & 6.0 & 2.5 & 8.5 \\
\hline $\mathbf{6 0 0}$ & 6.5 & 2.5 & 9.0 \\
\hline $\mathbf{7 0 0}$ & 7.0 & 3.0 & 10.0 \\
\hline $\mathbf{8 0 0}$ & 8.0 & 3.0 & 11.0 \\
\hline
\end{tabular}

Kaynak: Defra, 2007 
Bunlara ek olarak, çiftlik hayvanlarında verimlilik oranı refahın önemli göstergeleri arasındadır. Hayvanların refah koşullarının iyileştirilmesi ile türüne özgü koşullara sahip olmaları ile birlikte uzun vadede verimlilik oranları da iyileşmektedir.

Ayrıca çiftlik hayvanlarının strese maruz kalması süt ve yumurta üretimi ile et kalitesini düşürmekte ve kilo verme ve doğurganlığı etkileyerek refah üzerinde negatif göstergelere neden olmaktadır (Vetter et al., 2014). Stres koşulları altında meydana gelebilecek karkas kusurları da büyük ekonomik kayıplara neden olmakta ve yıllık olarak birkaç milyon dolar kayba neden olduğu tahmin edilmektedir (McKenna et al., 2002).

\section{Dünya'da Hayvan Refahı Uygulamalarının Ekonomik ve Sürdürülebilirlik Açısından Değerlendirilmesi}

\subsection{Dünya'da Hayvan Refahı Uygulamalarının Ekonomik Açıdan Değerlendirilmesi}

Hayvan refahı, sadece hayvancılık işletmelerini ilgilendiren bir konu olmayıp refahın iyileştirilmesi ile birlikte işletmelerin yanında piyasada ve toplumda da olumlu ekonomik etkilere sahiptir.

İyileştirilmiş hayvan refahının hayvancılık işletmelerindeki en önemli ekonomik etkileri hayvan ölüm oranını azaltması, hayvan sağlığını iyileştirmesi ve hastalıklara karşı direnci güçlendirerek ilaç kullanımını azaltmasıdır. Dawkins (2016:2), yapmış olduğu çalışmada, iyi refah koşullarının ekonomik etkinliğe en önemli katkısının hayvan ölüm oranının azaltması olduğunu ortaya koymuştur.

Şekil 2'de ise çiftlik hayvan refahı uygulamalarının girdi, üretim süreci ve çıktı aşamasındaki etkileşimleri ve ekonomi ilişkisi verilmiştir. 1. Çizgide çiftlik hayvan refahının girdileri etkilediği gösterilmektedir. Örneğin, hayvan refahı seviyesi hayvan ölüm ve yaralanma oranlarını etkilemektedir. 2. Çizgide üretim sürecinden kaynaklanan dışsallıkların çiftlik hayvan refahını etkilediğine dikkat çekilmiştir. 3. Çizgi ise çiftlik hayvan refahının çıktıları, miktar ve kalite bakımından etkilediği gösterilmektedir. 4. Çizgide, çiftlik hayvan refahının sağladığı sosyal faydalar ve insan refahına etkisi ortaya konmuştur. Bu kapsamda değerlendirildiğinde, hayvan refahı, girdi, üretim süreci, çıktı etkileşiminin ekonomik ve insan refahıyla yakından ilişkili olduğu daha iyi anlaşılmaktadır.

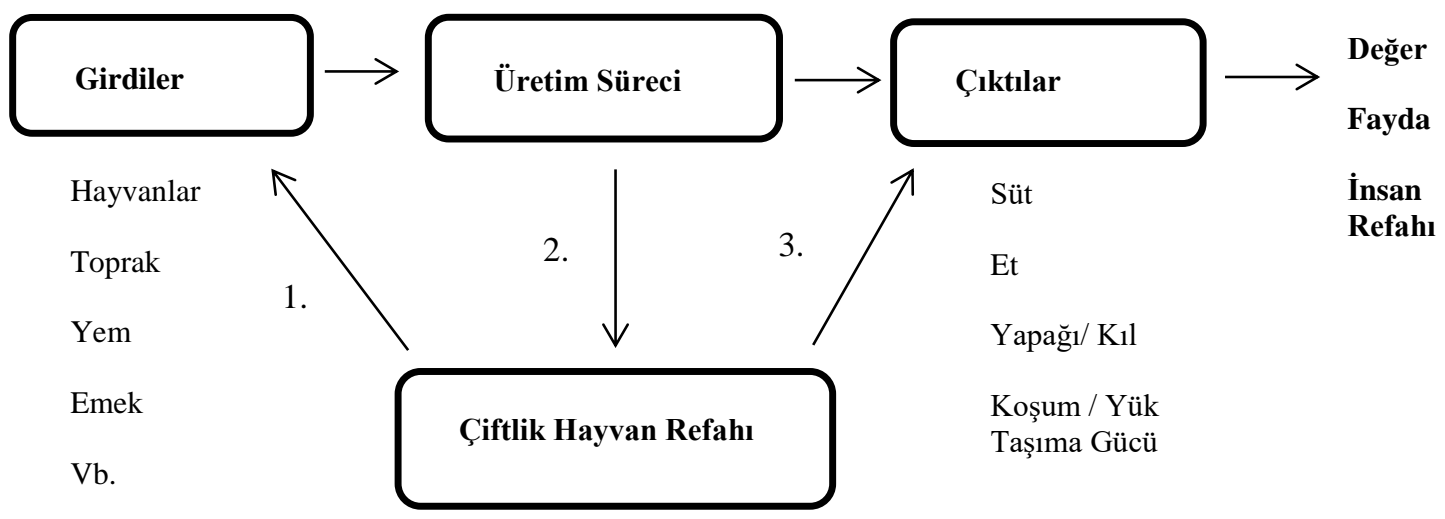

Şekil 2: Çiftlik hayvan refahı ve üretim süreci arasındaki ekonomi ilişkisi

Kaynak: FAWC, 2011:4 
Blokhuis ve arkadaşlarının 2013'te yapmış oldukları çalışma, 7 farklı ülkede tüketicilerin hayvan refahı ile ilgili düşüncelerini ortaya koyması açısından son derece önemlidir (Tablo 4). Çalışma sonucunda her ülkede tüketicilerin hayvan refahını önemli bulduğu, ancak çoğunluğunun alışveriş sırasında hayvan refahını dikkate almadığı belirlenmiş̧ir. Aynı çalışmanın bir diğer önemli bulgusu ise, tüketiciler içinde tavukların kötü refah koşullarına maruz kaldıklarını düşünenlerin oranının, sığırların kötü refah koşullarına maruz kaldığını düşünenlerden oldukça yüksek olmasıdır.

Tablo 4: Hayvan refahı endișeleri

\begin{tabular}{|l|l|c|c|c|}
\hline & $\begin{array}{l}\text { Hayvan Refahının } \\
\text { Önemi ( H. } \\
\text { refahının önemli } \\
\text { olduğunu } \\
\text { düşünenler \%) }\end{array}$ & $\begin{array}{l}\text { Siğırların Kötü } \\
\text { Refah Koşullarına } \\
\text { Sahip Olduğunu } \\
\text { Düşünenler (\%) }\end{array}$ & $\begin{array}{l}\text { Tavukların Kötü } \\
\text { Refah Koşullarına } \\
\text { Sahip Olduğunu } \\
\text { Düşünenler (\%) }\end{array}$ & $\begin{array}{l}\text { Alsşveriş Yaparken } \\
\text { Refahı } \\
(\%)\end{array}$ \\
\hline Düşünenler \\
\hline İsveç & $\% 84$ & $\% 3$ & $\% 47$ & $\% 12$ \\
\hline $\begin{array}{l}\text { Birleşik } \\
\text { Krallık }\end{array}$ & $\% 83$ & $\% 5$ & $\% 40$ & $\% 23$ \\
\hline Hollanda & $\% 69$ & $\% 12$ & $\% 56$ & $\% 13$ \\
\hline Fransa & $\% 65$ & $\% 9$ & $\% 50$ & $\% 23$ \\
\hline İtalya & $\% 87$ & $\% 15$ & $\% 57$ & $\% 41$ \\
\hline Macaristan & $\% 83$ & $\% 16$ & $\% 28$ & $\% 24$ \\
\hline
\end{tabular}

Kaynak: Blokhuis ve ark., 2013:105

İyileştirilmiş hayvan refahının piyasadaki olumlu ekonomik etkilerinin başında kurumların sosyal sorumluluğa katkı sağlama girişimleri gelmektedir. Tüketicilerin iyi refah koşullarından yetiştirilmiş hayvanlardan elde edilen gıdalara ödeme istekliliğindeki artış, iyileştirilmiş hayvan refahının piyasadaki önemli ekonomik etkileri arasındadır (McInerney, 2004). Lama ve arkadaşlarının 2017'de Meksika'da yaptığı çalışma tüketicilerin hayvan refahı hakkında daha fazla bilgiye sahip olma isteğini ortaya koymuştur. Ayrıca insan sağlığına katkılarından ve ürün kalitesi açısından daha fazla ödeme istekliliğinin olduğu bulgusuna ulaşmıştır (Lama et al, 2017:112). Snooper'ın 2014'te gerçekleştirdiği tüketici anketi sonuçları da tüketicilerin üretim sistemleri ile ilgili bilgi eksikliği olduğu ve bu nedenle daha güvenilir ve doğru bilgi edinmeye ihtiyaç duyduklarını ortaya koymuştur. Amerika'da 2004 y1lında gerçekleştirilen bir başka çalışma, insani koşullarda yetiştirilmiş hayvansal gıdalar için tüketicilerin \%31'inin \%5 daha fazla ödeme istekliliği, \% 23’ünün \%10 daha fazla ödeme istekliliği taşıdığı bulgusuna ulaşmıştır (AAA, 2004 ). Makdisi ve arkadaşlarının (2011), Almanya'da gerçekleştirdiği çalışmada ise, çiftlik hayvan refahının sertifikalı olması halinde \%27'lik fiyat artışına razı olduklarını ortaya koymuştur.

Ödeme istekliliğindeki artış, arz tarafında hayvan refahının iyileştirilmesi için başlangıç aşamasında katlanılması gereken maliyet artışının neden olduğu fiyat artışı ile orantılı olduğu takdirde piyasa başarısı sağlanacaktır. Piyasa başarısının sağlanabilmesi, işletmelerde optimal hayvan refahı seviyesine ulaşılması ile mümkündür.

McInerney, 2004 yılında yapmış olduğu çalışmada hayvancılık işletmelerinde hayvanlarda algılanan refah seviyesi ile çiftlik hayvanı verimliliği arasındaki ilişkiyi açıklamıştır. "A" noktası hayvanların doğasında var olan ve insanların verimlilik arttırmak amacıyla müdahale etmediği doğal refah seviyesidir. Girdi kalitesinin arttırılmasıyla örneğin barınak ve yem 
koşullarının iyileştirilmesi ile birlikte "A" noktasından "B" noktasına gidildikçe hem refah seviyesi hem de verimlilik artacaktır. "B" noktasından "C" noktasına gidildikçe girdi kalitesi arttırılmaya devam ettirilse dahi verimlilik artarken refah seviyesi hayvanların biyolojik sınırlarından dolayı artmayacaktır. İşletmelerde verimliliğin maksimize edildiği ve refah seviyesinin doğal refah seviyesine eşdeğer olduğu "C" noktası işletmelerde optimal hayvan refahı seviyesi olarak tanımlanmaktadır. Optimal hayvan refahı seviyesinde üretim yapan işletmeler, piyasadaki arz talep dengesini sağlayacak ve piyasa başarısı elde edilecektir.

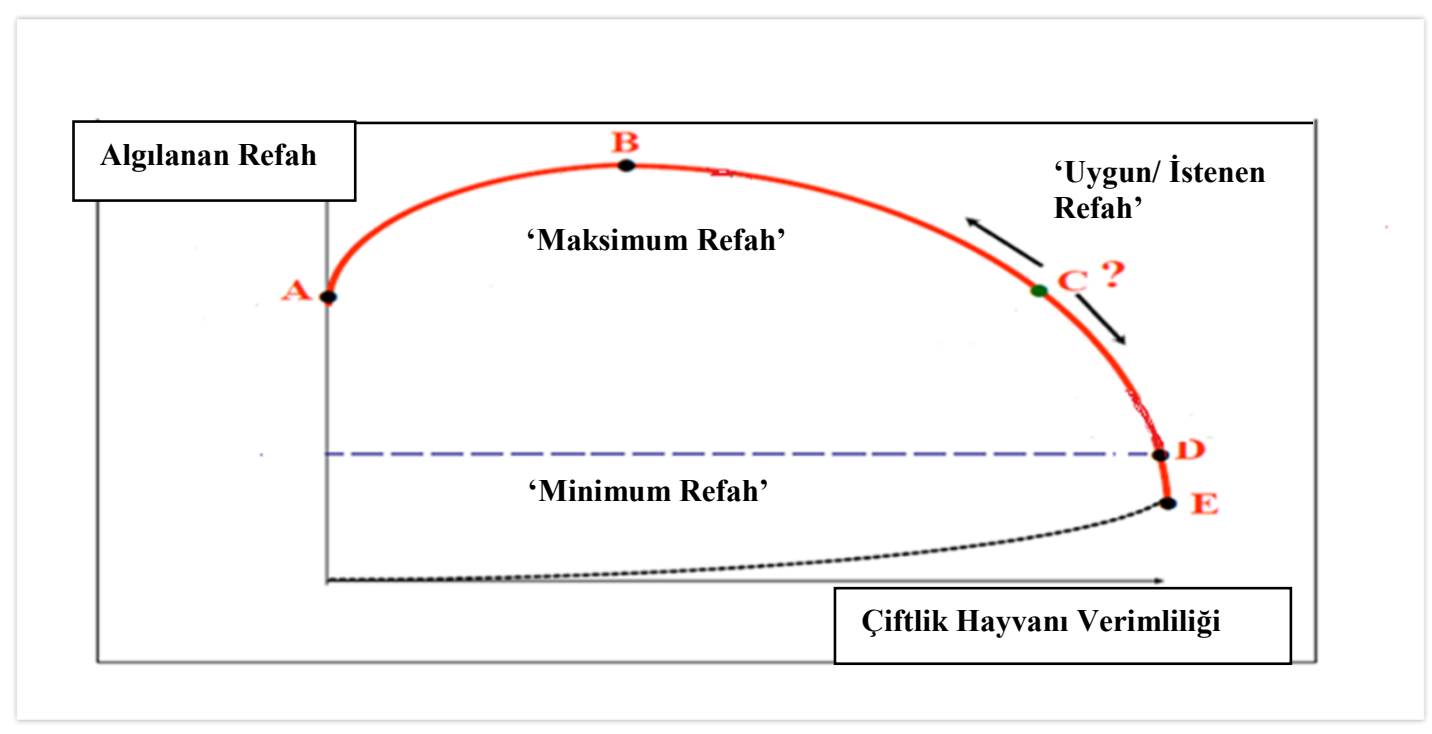

Şekil 3: Optimal hayvan refahı

Kaynak: McInerney, J.P. 2004:18

\subsection{Dünya'da Hayvan Refahı Uygulamalarının Sürdürülebilirlik Açısından Değerlendirilmesi}

Sürdürülebilirlik kavramı ekonomik, ekolojik ve sosyal yönleri olan çok boyutlu bir kavramdır (McIvor, 2016:4). Sürdürülebilir bir sistem; çevreye duyarlı, ekonomik açıdan uygulanabilir ve sosyal açıdan sorumluluk sahibi olmalıdır (Allen, 1991).

Hayvan Refahı Evrensel Beyannamesi, hayvan refahının sağladığı sosyal faydaları ortaya koymuştur. $\mathrm{Bu}$ sosyal faydaların içerisinde yer alan sürdürülebilirlik hedefleri ve iklim değiş̧ikliği ile mücadele sürecinde hayvan refahı vazgeçilemez bir unsur olarak ifade edilmiştir. Hayvan refahının iyileştirilmesi ile değişen hayvancılık uygulamaları sürdürülebilir üretimi beraberinde getirecektir (WSPA, 2017).

Artan talep doğrultusunda yalnızca hayvan sayılarını arttırmak, çiftlik hayvanları üretiminin olası çevresel etkileri göz önüne alındığında, sürdürülebilir bir seçenek değildir (FAWC, 2014). Ayrıca, et ve sütte $\% 21$ ve $\% 16$ olan israf oranları başarıyla azaltılsa bile 2050 'de talebin karşılanamayacağı öngörülmektedir (FAO, 2012). Bu nedenlerle sürdürülebilirlik hedefleri doğrultusunda hayvan refahı sürecin temel unsurları arasında yer almaktadır. Hayvansal üretimin sürdürülebilirlikteki yerinin anlaşılması çarpıcı şekilde artması beklenen küresel gıda talebi nedeniyle giderek daha da gerekli hala gelmektedir (M'hamdi et al., 2017:1). 
1950'lerden sonra "Yeşil Devrim"in gelişmesiyle sözde modern tarım yöntemleri yaygınlaşmış ve hayvancılık işletmelerinde yoğun üretim sistemlerine geçilerek hayvanlar kötü muamelelere maruz bırakılmıştır. $\mathrm{Bu}$ yeni üretim sistemlerinin yaşamın sürdürülebilirliği üzerindeki olumsuz etkisi bilimsel olarak ispatlanmıştır. Yeşil devrimin bir sonucu olarak ortaya çıkan sorunlar, insan hayatının şimdiki ve gelecekteki sürdürülebilirliğine zarar verdiği için sonlandırılmalıdır (Susanto, 2015). Yeşil devrim, sadece çevresel zararlar değil aynı zamanda sosyal ve ekonomik boyutlara da zarar vermiştir. Bu olumsuz etkileri ortadan kaldırmak için gerekli olan toplumsal değişim, organik tarımın temel hedefi olmuştur. "Yeşil Devrim" ile yaygınlaşan kötü barınak koşullarına ve insanlık dışı muameleye tepki olarak gündeme gelen hayvan refahı, organik tarımın temel unsurları içerisinde yer almaktadır. Çevre dostu bir tarım, gıda güvenliği ve hayvan refahı sürdürülebilir kalkınma hedeflerinde sürecin ayrılmaz unsurlarıdır.

Hayvancılık sektörü şu anda dünyanın en büyük doğal kaynak kullanıcısıdır: tarımsal arazilerin\%80'i otlatma veya hayvansal yem üretimi için, küresel su kullanımının \% 8'i özellikle yem bitkilerinin sulaması için kullanılmaktadır (Steinfeld et al., 2006).

Küresel nüfusun, 2050 yılına kadar 9 milyarı aşması beklentisi; yaşam beklentisi ve kentleşmenin artması, göçün hızlanması ve sınırlı çevresel kaynaklar ışığında, bu nüfus eğilimleri nesiller için geniş kapsamlı etkilere sahip olacaktır. 2050 yılına kadar en az 3 milyar insanın orta sınıfa girmesi beklenmektedir. Birleşmiş Milletler Gıda ve Tarım Örgütü (FAO), bunun süt ve et gibi yüksek kalitede protein talebinde $\% 60$ 'lık bir artışa neden olacağını tahmin etmektedir (FAO, 2012). Bütün bu nedenlerle sürdürülebilirlik kapsamında hayvanc1lık son derece önemlidir.

\subsection{Türkiye'deki Gelişmeler}

Dünya'da yaşanan gelişmeler doğrultusunda, Türkiye'de de hayvan refahına ilişkin tartışmalar ivme kazanmıştır. Tüketici taleplerinin değişmeye başlaması, üreticilerin daha fazla kar elde etmek istemesi başta olmak üzere ekonomik kaygıları, sürdürülebilirliğin tehdit edildiği günümüz yoğun üretim sistemlerine getirilen eleştiriler vs. birçok nedenle hayvan refahı konusu Türkiye'de de güncel konular arasına girmiştir. Gıda zinciri ve ekolojik üretim sistemlerinin önemli bir unsuru olan hayvan refahı, iyi tarım uygulamaları kapsamında da son derece önem kazanmıştır (Demirel ve Çak, 2016). GTHB 2018-2022 Stratejik Planı'nda, güvenilir gıda arzını temel alan hayvan sağlığı uygulamaları aracıllı̆̆ıla; hastalık ve zararlılardan dolayı oluşacak ekonomik kayıpları azaltarak hedeflenen üretim seviyelerine ulaşmak, hayvan refahını korumak, üreticilerin gelirlerini arttırarak iç ve dış ticareti kolaylaştırmak, temel hedefler arasında yer almıştır (GTHB, 2017).

Gıda, Tarım ve Hayvancılık Bakanlığı faaliyet raporlarına göre Türkiye'de hayvancılık sektöründe 2000'li y1llardan itibaren büyük yol kat edilmiştir. Türkiye'de bu süreçte en önemli yasal düzenleme 2004 yılındaki 5199 Sayılı Hayvanları Koruma Kanunu olmuştur (Yaşar ve İzmirli, 2006: 52). Ancak söz konusu kanun sadece çiftlik hayvanlarına ilişkin olmayıp laboratuvar hayvanlarını, pet hayvanlarını ve yaban hayvanlarını da kapsamaktadır.

Türkiye'deki söz konusu mevzuat çalışmaları öncelikli olarak nakil ve kesim koşullarını belirlemeye yönelik olmuştur. 2004'ten sonraki önemli gelişmeler; 24.12.2011 Tarihli 28152 Sayılı "Hayvanların Nakilleri Sırasında Refahı ve Korunması Yönetmeliği", 22.11.2014 Tarihli 29183 Sayılı " Çiftlik Hayvanlarının Refahına İlişsin Genel Hükümler Hakkında Yönetmelik" ve 22.11.2014 Tarihli 29183 Sayılı " Buzağıların Korunması ile İlgili Asgari Standartlara İlişkin Yönetmelik"'in kabul edilmesi olmuştur. Ancak söz konusu yönetmeliklerin uygulanması sürecindeki güçlükler ve denetim yetersizliği yönetmeliklerle 
hedeflenen başarıya ulaşılamamasına neden olmuştur. Şeker ve arkadaşlarının (2011) Elazı̆̆ ilinde yapmış olduğu çalışmada, satın aldıkları kırmızı eti güvenilir bulanların oranı \%78.8 olarak tespit edilmiş, tüketicilerin \%22'sinin hayvan refahında hastalıkların öncelikli olarak düzeltilmesi gerektiğini düşündüklerini ortaya konmuştur. Örneğin, büyükbaş hayvancılıkta, üretim yöntemlerinde karşılaşılan sorunlar nedeniyle görülen Deli Dana hastalığı (Bovine Spongiform Encephalopathy: BSE), birçok kişinin hayatına mal olmuştur. Bununla birlikte hayvanlarım imha edilmesi sürdürülebilirliği tehdit etmiş ve büyük ekonomik kayıpları da beraberinde getirmiştir (Duru ve Şahin, 2004).

Kılıç ve arkadaşlarının (2013: 29) Afyonkarahisar' da gerçekleştirdiği koyunculuk işletmeleri çalışanlarını kapsayan çalışma, üreticilerin hayvan refahı ile ilgili şuana kadar hiçbir eğitim almadıklarını ortaya koymuştur. Bu nedenle Türkiye, Avrupa Birliği ülkelerini rol model alarak, hayvan refahının iyileştirmesinde en önemli faaliyet alanlarından birinin eğitim ve öğretim olduğunu vurgulamıştır. Bu kapsamda, "Hayvan Refahı" veterinerlik ve zootekni bölümlerinde müfredatta yer almaya başlamıştır (Yaşar ve İzmirli, 2006). Ayrıca hayvansal üretimde bulunanlar için eğitimi programları hazırlanıp katılım için teşvikler yapılmıştır. Hayvan refahının iyileştirilmesi sürecinde, konu ile ilgili ulusal ve uluslararası projelerin de olumlu etkiler yapacağı düşünülmektedir (Fidan, 2012).

Türkiye, Avrupa Birliği’ne uyum müktesebatında hayvan refahını iyileştirici önlemler almış; ancak hijyen, barınakların tasarımı konularında hala Avrupa Birliği standartlarına ulaşamamıştır. Kalite ve hijyen bakımından istenilen seviyeye gelinmemesi, hayvansal ihracat potansiyelini kısıtlayıcı bir faktör olmuştur (Gümüş ve Çınar, 2016).

Özetle, Türkiye'de mevzuat çalışmaları dünyadaki gelişmelere paralel olarak artmakla birlikte, mevzuatlara uyumun genellikle gönüllülük esasına dayanması ile denetim ve kontrol aşamalarında kontrol mekanizmalarında yaşanan sorunlar, yaptırımların yetersiz olması vs. birçok nedenle mevzuat çalışmalarıyla hedeflenen refah seviyesinin uygulamaya geçirilmesi sürecinde istenilen başarıya ulaşılamamasına neden olmuştur.

\section{Sonuç ve Öneriler}

Dünya'da hayvan refahı son dönemde tartışılan konular içindedir ve ülkeler ulusal mevzuatlarında yer vermektedir ya da yer vermeye başlamaktadır. Nitekim, ABD ve AB'nin hayvan refahı ile ilgili yasaların ilk belirleyicisi olmaları ve Türkiye'de de son dönemlerde mevzuatta uyumun sağlanması dikkat çekicidir. Yetiştiricilik aşamasındaki refaha yönelik yasal mevzuatların çıkarılması, dış ticarette hayvan refahı uygulamalarının koşul olarak getirilmesi, tüketicilerin bilinçlenmeye başlaması itici güç olarak hayvan refahını pozitif etkileyecek en önemli faktörlerdir. Ancak, hayvan refahı uygulamalarının sonuçlarını değerlendirmeye yönelik önemli sorunlar yaşanmaktadır. Bu sorunların giderilebilmesi için ülkelerde mevzuat değişimleriyle birlikte, uygulama ve denetimin de aktif olması gerekliliği ortaya çıkmaktadır. Diğer yandan, hayvan refahını ekonomik ve sürdürülebilirlik açısından ele alan araştırma ve çalışmaların azlığı dikkati çekmektedir. Gelişmiş ülkelerde bile tüketicilerin hayvan refahı algısının gelişmesine rağmen, alışverişlerde hayvan refahını yeterince dikkate almamaları dikkat çekicidir. Bu durum, tüketici cephesinin iç pazarda itici güç olmasını olumsuz etkilemektedir. $\mathrm{Bu}$ kapsamda gıda ürünlerinde etiketlemenin geliştirilmesi ve hayvan refahına uyulup uyulmadığının da etiket üzerinde yer alması önemlidir. Hayvan refahının iyileştirilmesi sürecinde bir diğer önemli aktör politika belirleyicilerdir. Politika belirleyiciler, çiftçileri bilinçlendirici yerinde eğitim programları ve yeni politika araçları geliştirilmeli; ekonomik teşvikler ve para cezaları uygulanmalıdır. Ek 
olarak, üreticilerin ekstra ücret beklentisi, gıda pazarlama zincirlerinde güvence altına alınarak iyileştirilmiş hayvan refahının sürdürülebilirliği sağlanmalıdır.

Sonuç olarak, hayvan refahı ile sürdürülebilirlik ve ekonomi ilişkisini ülke ve bölge bazında dikkate alacak multidisipliner araştırmaların desteklenmesinin gıda güvencesi açısından son derece önemli olduğu ortaya çıkmaktadır. 


\section{KAYNAKÇA}

ALLEN, P., VAN DUSEN, D., LUNDY, J., and GLIESSMAN, S. (1991) "Integrating Social, Environmental, and Economic Issues in Sustainable Agriculture", American Journal of Alternative Agriculture, 6(1):34-19.

Animal Agriculture Alliance (AAA), 2004. Consumers Attitudes About Animal Welfare: 2004 National Public Opinion Survey.

BARTUSSEK, F. (2001), "An Historical Account of the Development of the Animal Needs Index ANI-35L as Part of the Attempt to Promote and Regulate Farm Animal Welfare in Austria: An Example of the Interaction Between Animal Welfare Science and Society", From http://dx.doi.org/10.1080/090647001316923036

BLOKHUIS, H., MIELE, M., VEISSIER, I. and JONES, B. (2013), "Improving Farm Animal Welfare". From www.WageningenAcademic.com/welfarequality

Brambell Report, 1964, Report of the Technical Committee to enquire into the welfare of animals kept under intensive livestock husbandry systems. Her Majesty's Stationery Office, London, UK.

Compassion in World Farming (CIWF), 2014, The Food Security, Sustainability, Public Health and Animal Welfare Implications of Livestock Production.

DAWKINS, M.S. (2016), “Animal Welfare and Efficient Farming: is Conflict Inevitable?", From http://dx.doi.org/10.1071/AN15383

DEMIREL, A.F. ve ÇAK, B. (2016), “Türkiye ve Avrupa Birliği’nde İlgili Mevzuatlar Açısından Hayvan Refahı Uygulamalarının Gıda Güvenliğindeki Önemi” Van Vet J, 2016, 27 (2) 111-116

DERELİ FIDAN, E., (2012), "Türkiye'de Çiftlik Hayvanları ile İlgili Refah Uygulamaları" Animal Health, Prod. and Hyg. (1): 39 - 46.

DURU, M. ve ŞAHIN, A. (2004), “Türkiye'de Sağlıklı ve Güvenli Hayvansal Üretimin Gerekliliği”, Hayvansal Üretim 45(1): 36-41.

ERDAL, S. (2012), "Küreselleşme Sürecinde Refah Devleti Uygulamaları Açısından İsveç Modelinin Değerlendirilmesi”. Dokuz Eylül Üniversitesi, Sosyal Bilimler Enstitüsü Maliye Anabilim Dalı, Maliye Programı Doktora Tezi.

Farm Animal Welfare Committe (FAWC), 2011, Economics and Farm Animal Welfare, London, United Kingdom. From http://www.defra.gov.uk/fawc/

Food and Agriculture Organization (FAO), 2012, "World agriculture towards 2030/2050: The 2012 Revision". ESA Working Paper No. 12-03, Rome.

GTHB, (2017) 2018-2022 Stratejik Plan, www.tarim.gov.tr/SGB/Belgeler/stratejikplan.pdf. [Erişim: 01.12.2017].

GÜMÜŞ, E. ve ÇINAR, H. "Türkiye, Amerika Birleşik Devletleri ve Avrupa Birliği Sığır Eti Sektörlerinin Karşılaştırılması ve Dış Ticaret Açısından Değerlendirilmesi” Harran Üniv Vet Fak Derg, 5(2) 177-183.

KILIÇ, İ., BOZKURT, Z., TEKERLİ, M., KOÇAK, S. ve ÇELIKELOĞLU, K. (2013), "Afyonkarahisar İli Koyunculuk İşletmeleri Çalışanlarının Hayvan Refahını Etkileyen Faktörlerle İlgili Algıları” Lalahan Hay. Arast. Enst. Derg. 53 (1) 29-38. 
LAMA, G.C.M., ESTEVEZ-MORENO, L.X., SEPULVEDA, W.S., ESTRADACHAVERO, M.C., RAYAS-AMOR, A.A., VILLARROEL, M. and MARIA, G.A. (2017), "Mexican Consumers' Perceptions and Attitudes Towards Farm Animal Welfare and Willingness to Pay for Welfare Friendly Meat Products", Meat Science 125:106-113.

MAKDISI, F. and MARGGRAF, R. (2011), "Consumer Willingness to Pay For Farm Animal Welfare in Germany- The Case of Broiler", Department of Agricultural Economics and Rural Development, University of Göttingen, Platz der Göttinger Sieben, Göttingen, Germany

MATHENY, G. and LEAHY, C. (2007), "Farm Animal Welfare, Legislation and Trade". http://law.duke.edu/journals/lcp.

M'HAMDI, N., DAREJ, C., M'HAMDI, H., ATTIA, K., LANOUAR, L., CHOUCHEN, R., SADKAOUI, G. and ABBES, A. (2017), Assessment of Sustainability of Smallholder Beef Cattle Farms in the North of Tunisia, Journal of Animal Research and Nutrition, 2, 1:3 http://www.imedpub.com/.

MCINEMEY, J., (2004), "Report on a Study Undertaken for the Farm \& Animal Health Economics Division of Defra".

MCIVOR, S. (2016), "Integrating the Welfare Interests of Humans and Animals", UFAW Animal Welfare Conference, 23rd June 2016.

MCKENNA, D., ROEBER, D., BATES, T., SCHMIDT, T.B., HALE, D.S., GRIFFIN, D.B. et al. (2002), "National Beef Quality Audit-2000: Survey of Targeted Cattle and Carcass Characteristics Related to Quality", Quantity and Value of Fed Steers and Heifers. Journal of Animal Science 80: 1212- 1222.

Resmi Gazete, (2004), "Hayvanları Koruma Kanunu”, Tarih: 01.07.2004, Sayı: 25509, Kanun No: 5199, Kanun Kabul Tarihi: 24.06.2004.

SEO, T., DATE, K., DAIGO, T., KASHIWAMURA, F. and SATO, S. (2007), "Welfare Assessment on Japanese Dairy Farms Using the Animal Needs Index, Universities Federation for Animal Welfare", 16: 221-223, UK.

SPOONER, J.M., SCHUPPLI, C.A. and FRASER, D. (2014), "Attitudes of Canadian Citizens toward Farm Animal Welfare: A Qualitative Study", Livestock Science 163:150-158, Animal Welfare Program,Faculty of Landand Food Systems, University of British Columbia, Vancouver, Canada.

STEINFELD, H., GERBER, P., WASSENAAR, T., CASTEL, V., ROSALES, M. and DE HAAN, C. (2006), "Livestock's long shadow - Environmental issues and options", FAO Agriculture Technical Paper, Rome.

SUSANTO, I.R. (2015), "Sustainable Organic Farming For Environmental Health: A Social Development Model", Internetional Journal of Scientific and Technology Research 4, 5: 196-211.

ŞEKER, İ., ÖZEN, A., GÜLER, H., ŞEKER, P. ve ÖZDEN, İ. (2011), “Elazı̆̆’ da Kırmızı Et Tüketim Alışkanlıkları ve Tüketicilerin Hayvan Refahı Konusundaki Görüşleri" Kafkas Univ. Vet. Fak. Derg.17 (4): 543-550.

Türk Dil Kurumu (TDK), http://www.tdk.gov.tr/, [01.08.2017]. 
VETTER, S., VASA, L. and ÓZSVARI, L., (2014), "Economic Aspects of Animal Welfare, Acta Polytechnica Hungarica, 11,7:119-134.

Welfare Quality (WQ) 2009, Assessment Protocol for Cattle, Welfare Quality Project Office, The Netherlands.

World Society for the Protection of Animals (WSPA), 2007, Universal Declaration on Animal Welfare.

YAŞAR, A. ve İZMİRLİ, S. (2006), “Türkiye'de Hayvan Gönenci (Refahı) İle İlgili Yasal Düzenlemeler", Vet. Bil. Derg., 22, 3-4: 51-56. 